\title{
Impact of climate change on agricultural production and adaptive measures: a case study on Kalapara, Patuakhali, Banngladesh
}

\author{
Khaled Ibne Amir ${ }^{1} \&$ Tanvir Ahmed ${ }^{2}$ \\ Geography \& Environment Department, University of Dhaka, Bangladesh
}

\begin{abstract}
Climate is very important physical condition of any area for the production of flora and fauna. Bangladesh is a tropical monsoon climate characterized by wide seasonal variation in rainfall, high temperature \& high humidity. That's why we enjoyed the beauty of six seasons in a year. Day by day the climatic elements like temperature, pressure, precipitation etc. are changed abruptly. As the result climate is also changed as the outcome of greenhouse effect. The term "green house effect" came from the Swedish Chemist Arrhenius in 1896. After that some evolution was seen in this terminology like as green house effect global warming climate change. This climate changed affects the total floral and faunal system of the earth. The environment or these systems can not supply the main ingredient of life. The food crisis is the outcome of climate change. Day by day the production of agriculture is decreasing and the seeds are being genetically weaken. For better survive we have to ensure our life danger free. These survive may be deterministic way or possibilistic way. For leading a better life adaptation to the climate change is very important. At the same time all types of indicator climate change should be reduced immediately. In the study area Kalapara the production of different crops are increasing. Awareness of the people, HYV crops, saline tolerant variety of crops, etc. are responsible for this positive situation. Though there are these types of positive scenario but the food security condition of the area is not satisfactory. Day by day the food security condition of the area is degrading. So some pragmatic steps should be taken to ensure the food security.
\end{abstract}

Keywords:Adaptation, Agricultural Production, Climate change, Food security, GIS, Remote Sensing.

\section{Introduction}

Over the past 250 years, deforestation, combustion of fossil fuels, and production of agricultural commodities such as rice and livestock have caused atmospheric concentrations of carbon dioxide $\left(\mathrm{CO}_{2}\right)$ and other green-house gases to rise significantly. According to the Intergovernmental Panel on Climate Change (IPCC), increases in greenhouse gas emissions have been associated with an increase in the mean global temperature of $0.3^{\circ} \mathrm{C}-0.6^{\circ} \mathrm{C}$ since the late 19 th century; by the end of the 21 st century, according the IPCC, greenhouse gas emissions could cause the mean global temperature to rise by another $1.4^{\circ} \mathrm{C}-5.8^{\circ} \mathrm{C}$ (Darwin, 2001). Climate change has a great impact on the various sectors. The agricultural sector is one of these. The relationship between climate change and agriculture is a vital issue for food security. The Earth's oceans will expand, raising sea levels, intrusion of saline water in agricultural land and reducing the amount of land available for agriculture. Extreme weather events, such as storms and floods, may increase in frequency (Darwin, 2001). These adverse situations can jeopardize the crop production in our country because it is one of the most risky areas in the world to be affected. Agricultural activities in Bangladesh are already highly susceptible to various elements of the biophysical system like- extreme temperature, early rain, excessive inundation,soil salinity,moisture insufficiently,extreme weather events,carbon dioxide emission etc.According to the IPCC's report of 2007, increases in precipitation extremes are very likely in the major agricultural zones of South Asia. On the one hand, crop production could be adversely affected by global warming through effects on soil moisture, pest/insects, weeds and plant diseases. On the other hand, enhanced carbon dioxide concentrations in the atmosphere would have beneficial effect on crop production (Rasheed, 2008). The combined effects of temperature, carbon dioxide etc. is playing negative roles in food grain production. Increase in annual rain fall with global warming would increase moisture supply in the soil. It could be beneficial for the dry season crops and also in the pre monsoon and post monsoon periods. At the same time, it should be noted that excess of soil moisture has also been found to impair the growth of rice plants \& trigger water logging condition in fields. Increased temperatures due to global warming are likely to have direct impact on crop production through the shortage of cool winter period. Aus and Aman rice and jute would probably benefit from the higher temperatures in their growing periods while the dry season or Rabi crops would have their yields reduced on account of higher minimum temperature at the time of its flowering in the pre monsoon season. Adaptation to climate change is therefore the process through which people reduce the negative effects of climate on their health and well-being and adjust their lifestyles to the new situation around them. IPCC defines adaptation as "Adjustment 
in natural or human systems in response to actual or expected climatic stimuli or their effects, which moderates harm or exploits beneficial opportunities" (IPCC Online, 2001).

Objectives: Some objectives of this study are mentioned in below.

$>$ Finding out the pattern of change of food production.

$>$ To indicate adaptive measures to combat the impacts of climate change on food security.
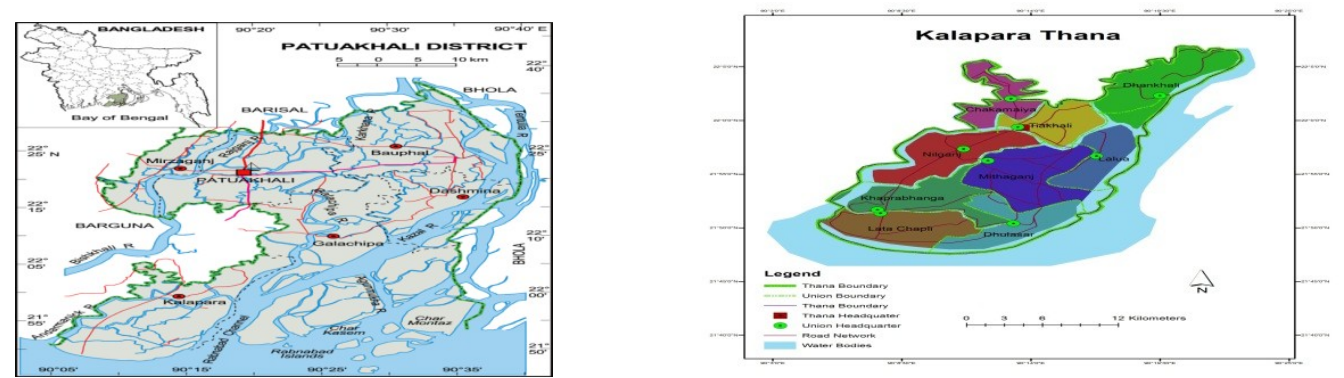

Map 1: Patuakhali District.(http://www.banglapedia.org/httpdocs/HT/P 0124.HTM accessed on 11 march 2012) \&Administrative Map of Kalapara (Developed by GIS)

\section{Methodology}

Methodology is the combination of many methods to conduct any research work. Despite this the methodology is the sum of many methods. Methodology of any research depends on the nature of research. The result of the research also depends on the methodology. In this research work different methods are applied to achieve the optimum results. Questionnaire method is mainly quantitative method on the other hand experts interview, field observation etc. are qualitative methods. These methods are simultaneously applied for fulfilling the objectives of research.

Any research needs different types of data and information. Researchers can collect these types of data from various sources. On the basis of sources there are three types of data sources. These are

$>$ Primary data: Questionnaire method, Field observation, Experts interview.

> Secondary data: BBS (Patuakhali census of agriculture, Patuakhali district statistics, Year book of agricultural statistics etc.), Bangladesh Meteorological Department., FAO, Agricultural Ministry of Bangladesh, Climate change and food security related different books, research papers and journals.

Then, the data were proceeding manually and presented mainly in tabular form. For easy understanding data were analyzed using percentage. For data analysis several techniques were used.

$>$ Using Statistical method: Collected data from different sources were compiled, tabulated and analyze through SPSS, MS EXCEL, MS word, MS Access and so on.

$>$ Using GIS and Remote Sensing techniques: GIS (Geographic Information System) and Remote Sensing were used for mapping, analysis and comparison. In graphic methods, the results of statistical data were presented by pie diagram, bar diagram, line graph and so on.

$>$ Photography: Different photographs were presented for actual understanding about the study area. These photographs were presenting the different sectors which are susceptible to the probable climate change of the study area.

\section{Result And Discussion}

Crop production trends in Bangladesh: Bangladesh is an agricultural country. Of the labor force about $65 \%$ is directly and indirectly dependent on the agriculture. The agriculture of Bangladesh is comprised of major and some minor crops. Fisheries, livestock, poultry etc. are some other sectors of agriculture. Though the most of the labor force of the country are engaged in agriculture but the GDP contribution of this sector is not satisfactory about $19 \%$. Despite these due to the fulfillment of the increasing domestic demand every year a lot of perishable food items are imported from abroad. As the world is changing due to the global economic recession so the prices of the commodities are increasing rapidly in the global market. So the food security condition of developing countries like Bangladesh is in a great threat. The growth in rice output over the last quarter of a century has been characterized by increasing reliance on irrigated boro cultivation and on using fertilizerintensive high-yielding varieties (HYVs). Boro rice now accounts for the bulk of rice grown in the country \& both aman and boro outputs are in fact volatile. But whereas aman has just two major peaks above the zero line (representing no change), it shows several troughs signifying fall in output. The nature of volatility of boro output is just the opposite, with changes mostly on the positive side. 

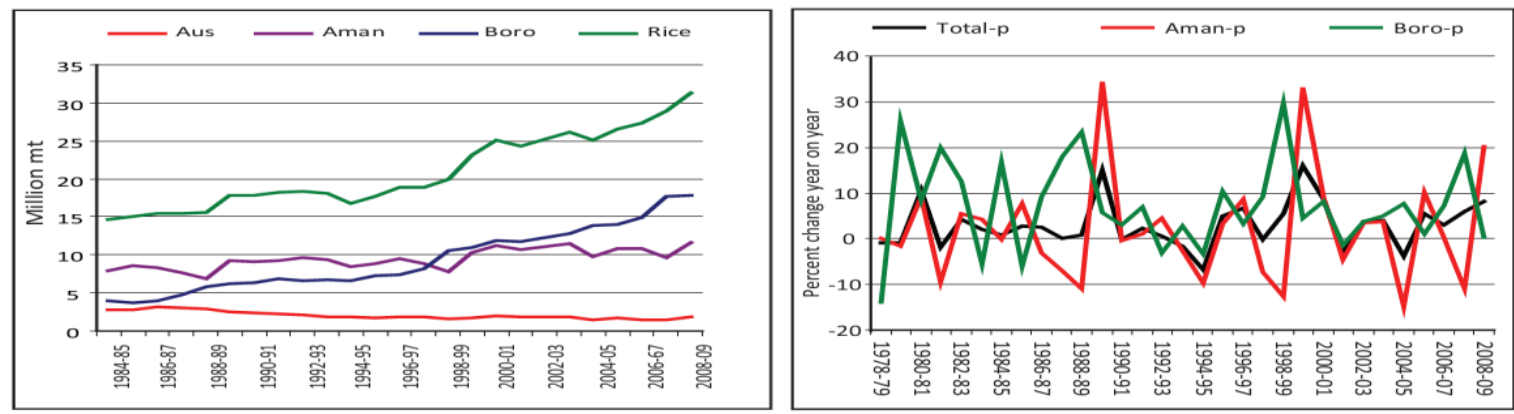

Figure 1 : Rice output trend in Bangladesh \&Year-to-year fluctuation in rice output (Asaduzzaman et al. 2010)

Agriculture of Patuakhali District: Patuakhali is a coastal district under the greater Barisal division. Agriculture is the main economic activity of this area. Rice is the dominant crop variety of the district. Production of the AUS, AMAN, BORO are given below. From below graph it is seen that due to cyclone "Sidr" on November 2007 the area and production of AUS, AMAN were drastically reduced. But in this crop variety the production trend has increased dramatically since the 2007.

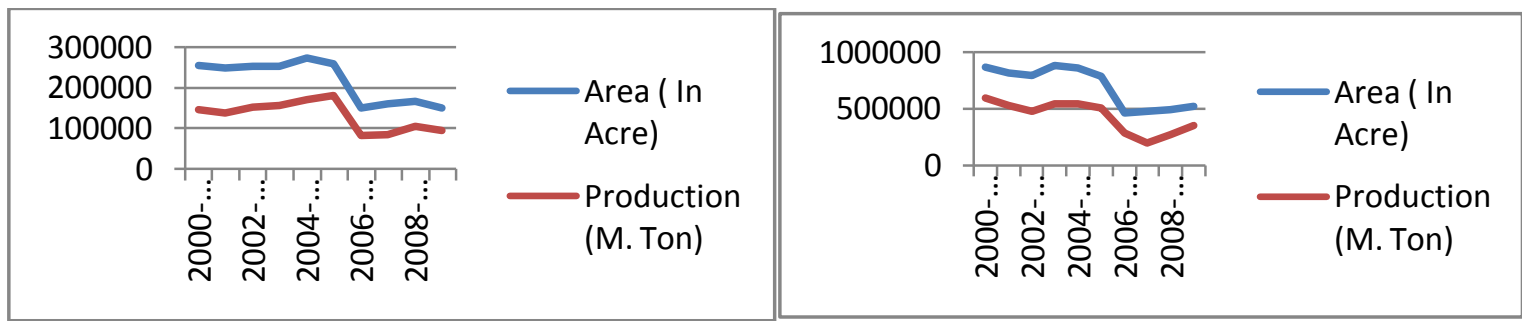

Figure 2: AUS \& AMAN rice production of Patuakhai. (Source: BBS)

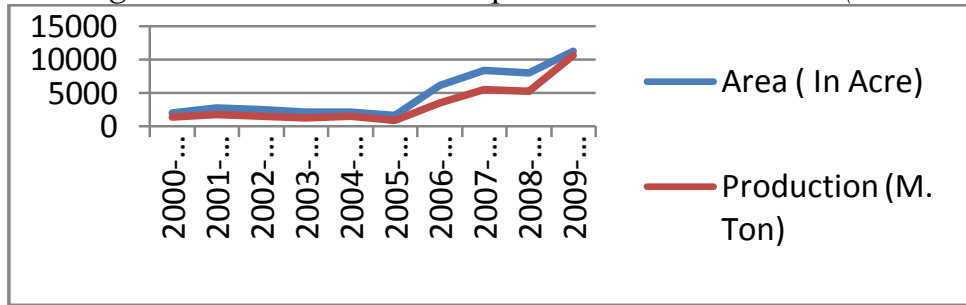

Figure 3: BORO rice production of Patuakhai. (Source: $B B S$ )

From this analysis it can be said the main crop of the Patuakhali is Aman. Most of the land area of this district is mainly single cropped, so the aman is prominently cultivated in this area

Agriculture of Kalapara: Kalapara is one of the most adjacent thana to the Bay of Bengal. Most of the people are dependent on the agricultural activities. Different relevant data are mentioned below on the basis of three agricultural censuses.

Table 1: Agricultural Statistics of Kalapara 1983-1984

\begin{tabular}{|c|c|c|c|c|c|c|}
\hline \multirow[t]{2}{*}{ Items } & \multirow[t]{2}{*}{ All Holding } & \multirow[t]{2}{*}{ Non- farm Holding } & \multicolumn{4}{|c|}{ Farm Holding } \\
\hline & & & Total & Small & Medium & Large \\
\hline No. of Holding & 25107 & 7783 & 17324 & 9526 & 5103 & 2695 \\
\hline Net cultivated area & 63058 & 30 & 63028 & 6940 & 20654 & 35434 \\
\hline Gross cropped area & & & 70663 & 7681 & 24022 & 38954 \\
\hline Intensity of cropping & & & 117 & 124 & 120 & 114 \\
\hline Irrigation (Holding reporting) & & & 408 & 115 & 180 & 113 \\
\hline Net irrigated area & & & 480 & 47 & 191 & 242 \\
\hline
\end{tabular}

(Source: BBS) 
Impact of climate change on agricultural production and adaptive measures: A case study on

Table 2: Agricultural Statistics of Kalapara 1996

\begin{tabular}{|l|l|l|l|l|l|l|}
\hline Items & All Holding & Non- farm Holding & \multicolumn{3}{l|}{ Farm Holding } \\
\cline { 3 - 7 } & & & Total & Small & Medium & Large \\
\hline No. of Holding & 34281 & 10555 & 23726 & 14894 & 6335 \\
\hline Net cultivated area & 66669 & 131 & 66538 & 9444 & 25764 \\
\hline Gross cropped area & & & 88450 & 12756 & 35846 & 31330 \\
\hline Intensity of cropping & & & 140 & 158 & 145 \\
\hline Irrigation (Holding reporting) & & & 869 & 334 & 352 \\
\hline Net irrigated area & & 1028 & 1028 & 401 \\
\hline
\end{tabular}

(Source: BBS)

Table 3: Agricultural Statistics of Kalapara 2008

\begin{tabular}{|l|l|l|l|l|l|l|}
\hline Items & All Holding & Non- farm Holding & \multicolumn{2}{l|}{ Farm Holding } \\
\cline { 4 - 7 } & & & Total & Small & Medium & Large \\
\hline No. of Holding & 49328 & 18880 & 30448 & 20178 & 8058 & 2217 \\
\hline Net cultivated area & 69229 & 175 & 69054 & 12255 & 31636 & 25162 \\
\hline Gross cropped area & & & 106852 & 18375 & 50482 & 37635 \\
\hline Intensity of cropping & & & 164 & 181 & 166 & 153 \\
\hline Irrigation (Holding reporting) & & & 2927 & 1261 & 1310 & 350 \\
\hline Net irrigated area & & & 4131 & 702 & 2216 & 1212 \\
\hline
\end{tabular}

(Source: BBS)

Crops of Kalapara: Crop is any plant product grown, harvested or collected for human use. Over 80 crops are grown worldwide, providing people with the major part of their food and supplying fibers, construction materials, pharmaceuticals, beverage, rubber, dyes and other materials. Crops grown for export are cash crops, while a cash crop is one grown in the interval between two main crops. In Kalapara there are wide varieties of crops (http://www.banglapedia.org/httpdocs/HT/C 0376.HTM accessed on 19 June 2012).

Major crops are grown on one percent or more of the gross-cropped area (GCA) of a country. In Bangladesh, only nine crops- rice $(73.94 \%)$, wheat $(4.45 \%)$, jute $(3.91 \%)$, rape and mustard $(3.08 \%)$, lentil $(1.54 \%)$, chuckling vetch $(1.25 \%)$, potato $(1.13 \%)$, sugarcane $(1.12 \%)$, and chili $(1.05 \%)$ are grown on 1 percent or more of the crop acreage (14.61 million ha) and maybe considered as major crops.

(http://www.banglapedia.org/httpdocs/HT/C 0376.HTM accessed on 19 June 2012).

Minor crops are grown on less than one percent of the gross cropped area (GCA) of a country. Gram, millets, maize, onion, black gram, sweet potato, groundnut, green pea, sesame linseed, garlic, pea, barley etc. are usually considered as minor crops. (http://www.banglapedia.org/httpdocs/HT/C 0376.HTM accessed on 19/06/12).

Table 4: Selected Agricultural statistics of Kalapara (2008)

\begin{tabular}{|l|l|l|l|}
\hline \multicolumn{2}{|c|}{ Cereals } & \multicolumn{2}{c|}{ Other crops } \\
\hline Crops & Area(In acre) & Crops & Area(In acre) \\
\hline Local Aus & 12369 & Wheat & 42 \\
\hline HYV Aus & 2169 & Maize & 401 \\
\hline Local Aman & 40394 & Jute & 28 \\
\hline HYV Aman & 21590 & Pulses & 15602 \\
\hline Local Boro & 212 & Oil seeds & 1404 \\
\hline HYV Boro & 445 & Sugar cane & 17 \\
\hline & & Potato & 194 \\
\hline
\end{tabular}

(Source: BBS)

Comparative analysis of present \& past crop production of Kalapara:

Table 5: Present area under crop production of Kalapara (From Primary Data)

\begin{tabular}{|l|l|l|l|}
\hline Types of crops & $0-1$ acre(Percentage) & $1-10$ acre(Percentage) & $>10$ acre(Percentage) \\
\hline IRRI & 58.33 & 65.4 & 33.33 \\
\hline Aus & 8.33 & 6.89 & \\
\hline Aman & & 13.79 & 66.67 \\
\hline Pulse & 8.33 & 13.79 & \\
\hline Nut & 16.67 & & \\
\hline Rabi crops & 8.33 & & 100 \\
\hline Total & 100 & 100 & \\
\hline
\end{tabular}


Impact of climate change on agricultural production and adaptive measures: A case study on

Table 6: Area under crop production about 10 years ago of Kalapara (From Primary Data)

\begin{tabular}{|l|l|l|l|}
\hline Types of crops & $0-1$ acre(Percentage) & $1-10$ acre(Percentage) & $>10$ acre(Percentage) \\
\hline IRRI & $74.99 \%$ & $71.42 \%$ & $50 \%$ \\
\hline Aus & $8.33 \%$ & & $16.67 \%$ \\
\hline Aman & & $7.14 \%$ & $33.33 \%$ \\
\hline Pulse & & $14.28 \%$ & \\
\hline Rabi crops & $16.67 \%$ & $7.14 \%$ & \\
\hline Total & 100 & 100 & 100 \\
\hline
\end{tabular}

Table 7: Present crop production in mounds of Kalapara (From Primary Data)

\begin{tabular}{|l|l|l|l|}
\hline Types of crops & $0-10$ mounds(Percentage) & $10-30$ mounds (Percentage) & $>30$ mounds (Percentage) \\
\hline IRRI & $37.5 \%$ & $57.14 \%$ & $77.78 \%$ \\
\hline Aus & $12.5 \%$ & $7.14 \%$ & $11.11 \%$ \\
\hline Aman & & $21.42 \%$ & $11.11 \%$ \\
\hline Pulse & $12.5 \%$ & $10.71 \%$ & \\
\hline Rabi crops & $37.5 \%$ & $3.57 \%$ & \\
\hline Total & $100 \%$ & $100 \%$ \\
\hline
\end{tabular}

Table 8: Crop production in mounds about 10 years ago of Kalapara (From Primary Data)

\begin{tabular}{|l|l|l|l|}
\hline Types of crops & $\begin{array}{l}0-10 \\
\text { mounds(Percentage) }\end{array}$ & $10-30$ mounds (Percentage) & $>30$ mounds (Percentage) \\
\hline IRRI & $49.99 \%$ & $70 \%$ & \\
\hline Aus & $7.14 \%$ & $10 \%$ & \\
\hline Aman & $14.28 \%$ & $20 \%$ & \\
\hline Pulse & $14.28 \%$ & & \\
\hline Nut & $3.57 \%$ & & \\
\hline Rabi crops & $10.71 \%$ & & \\
\hline Total & $100 \%$ & $100 \%$ & \\
\hline
\end{tabular}

Area under Fodder:There is 13 acres land under the cattle food or fodder.

Livestock of Kalapara (2008): Livestock is one of the most important animal resources to the people. The statistic of the livestock are given in below.

Table 9: Livestock of Kalapara (2008)

\begin{tabular}{|l|l|}
\hline Livestock type & Number \\
\hline Cattle \& Buffulo & 86840 \\
\hline Goat \& Sheep & 56678 \\
\hline Fowls \& Ducks & 736947 \\
\hline
\end{tabular}

(Source: BBS)

\section{Comparison of present \& past number of livestock:}

Table 10: Present number of livestock (From Primary Data)

\begin{tabular}{|l|l|l|}
\hline Types & Frequency & Percentage \\
\hline Cow & 104 & $10.45 \%$ \\
\hline Goat & 49 & $4.92 \%$ \\
\hline Sheep & 2 & $0.20 \%$ \\
\hline Duck & 379 & $38.09 \%$ \\
\hline Hen & 422 & $42.41 \%$ \\
\hline Buffalo & 5 & $0.50 \%$ \\
\hline Others & 34 & $3.41 \%$ \\
\hline Total & 995 & $100 \%$ \\
\hline
\end{tabular}

Table 11: Number of livestock about 10 years ago (From Primary Data)

\begin{tabular}{|l|l|l|}
\hline Types & Frequency & Percentage \\
\hline Cow & 225 & $12.43 \%$ \\
\hline Goat & 88 & $4.86 \%$ \\
\hline Sheep & 4 & $0.22 \%$ \\
\hline Duck & 663 & $36.62 \%$ \\
\hline Hen & 820 & $45.30 \%$ \\
\hline Buffalo & 10 & $0.55 \%$ \\
\hline Others & 0 & $0 \%$ \\
\hline Total & 1810 & $100 \%$ \\
\hline
\end{tabular}


Impact of climate change on agricultural production and adaptive measures: A case study on

\section{Pond area in acre (2008)}

Table 12: Pond area of Kalapara in acre

\begin{tabular}{|c|c|c|c|c|c|c|c|}
\hline Items & $\begin{array}{l}\text { All } \\
\text { Holdings }\end{array}$ & $\begin{array}{l}\text { With no cultivated } \\
\text { area }\end{array}$ & $\begin{array}{l}\text { With } 0.01- \\
0.04 \text { acrecultivated } \\
\text { area }\end{array}$ & Small & $\begin{array}{l}\text { Medium2.5- } \\
7.4 \text { acres }\end{array}$ & $\begin{array}{l}\text { Large } \\
7.5+\text { Acres }\end{array}$ & $\begin{array}{l}\text { Total } \\
\text { Farm } \\
\text { holding }\end{array}$ \\
\hline $\begin{array}{l}\text { Pond } \\
\text { area( single) } \\
\text { Owner }\end{array}$ & 2468 & 100 & 109 & 1124 & 741 & 394 & 2259 \\
\hline Pond(joint) & 567 & 26 & 41 & 273 & 168 & 60 & 521 \\
\hline $\begin{array}{l}\text { Area under } \\
\text { Permanent } \\
\text { Crops }\end{array}$ & 3835 & & 171 & 2043 & 1056 & 564 & 3664 \\
\hline $\begin{array}{l}\text { Current } \\
\text { fallow }\end{array}$ & 144 & & & 34 & 42 & 68 & 144 \\
\hline $\begin{array}{l}\text { Temporary } \\
\text { Crops net } \\
\text { area }\end{array}$ & 65250 & & 4 & 10178 & 30538 & 24530 & 65246 \\
\hline $\begin{array}{l}\text { Area under } \\
\text { pisciculture }\end{array}$ & 379 & 4 & 4 & 49 & 129 & 192 & 370 \\
\hline
\end{tabular}

(Source: BBS)

Agricultural Season: Agricultural season means the different seasons when the different kinds of agricultural products are grown on the basis of certain weather condition. In our country there are mainly two agricultural seasons these are Kharif and Rabi. (http://www.banglapedia.org/httpdocs/HT/C 0376.HTM accessed on 19/06/12)

Food security condition in Bangladesh: Bangladesh has lagged behind for a long time in terms of nutrition. About $60 \%$ of food is rice which is taken by people. The food items like as milk, meat, fish, vegetables etc are rarely taken by the people. So $26 \%$ people are suffering from malnutrition. Despite this due to the increasing prices of commodities these food security condition is degrading (Mahmood, 2012). In 2012 such type of report was published. According that report Bangladesh is $81^{\text {st }}$ among the 105 countries in food security condition by obtaining 34.6 points.

Table 13: Domestic production and per capita consumption of different food menus.

\begin{tabular}{|c|c|c|c|c|c|c|c|c|}
\hline \multirow[t]{2}{*}{ Items } & \multicolumn{4}{|c|}{ Domestic production } & \multicolumn{4}{|c|}{ Per capita consumption } \\
\hline & Unit & $1980-81$ & $1995-96$ & $2009-10$ & Unit & 1995-96 & $2009-10$ & Need \\
\hline \multicolumn{9}{|c|}{ Cereals } \\
\hline Rice & $000^{\prime} \mathrm{MT}$ & 13883 & 17687 & 32257 & Gram(g)/day & 464.3 & 416 & 312 \\
\hline Wheat & $000^{\prime} \mathrm{MT}$ & 1092 & 1369 & 969 & $\mathrm{~g} /$ day & 13.7 & 26.1 & 60 \\
\hline Others & 000'MT & 50 & 99 & 887 & g/day & 16.2 & 23 & 28 \\
\hline \multicolumn{9}{|c|}{ Non-cereals } \\
\hline Vegetables & 000'MT & 777 & 1254 & 2993 & g/day & 152.5 & 166.1 & 262 \\
\hline Potato & 000'MT & 963 & 1492 & 7930 & g/day & 49.5 & 70.5 & 130 \\
\hline Pulses & $000^{\prime} \mathrm{MT}$ & 217 & 525 & 221 & $\mathrm{~g} /$ day & 13.9 & 14.3 & 66 \\
\hline Oil seed & 000'MT & 245 & 471 & 377 & g/day & 9.8 & 20.5 & 38 \\
\hline Spices & $000^{\prime} \mathrm{MT}$ & 241 & 318 & 1240 & $\mathrm{~g} / \mathrm{day}$ & 9.1 & -- & 13 \\
\hline Fruits & $000^{\prime} \mathrm{MT}$ & 1374 & 1431 & 3172 & $\mathrm{~g} /$ day & 27.6 & 44.8 & 57 \\
\hline \multicolumn{9}{|c|}{ Fish \& animals } \\
\hline Meat & $000^{\prime} \mathrm{MT}$ & 243 & 540 & 1264 & $\mathrm{~g} /$ day & 12.1 & 19.1 & 22 \\
\hline Milk & 000’MT & 1160 & 1580 & 2365 & $\mathrm{~g} /$ day & 32.6 & 33.7 & 47 \\
\hline Fish & $000^{\prime} \mathrm{MT}$ & 650 & 1258 & 2899 & $\mathrm{~g} /$ day & 43.8 & 49.4 & 50 \\
\hline Egg & Million & 1240 & 2830 & 5742 & $\mathrm{~g} /$ day & 3.2 & 7.2 & 7 \\
\hline
\end{tabular}

(Source: Akanda, 2012)

National level availability of food: The food availability condition of Bangladesh is improving day by day. The increasing trends of the cereals crops are seen in the table. The HYV crops are playing a vital role behind this production. The non- cereals crops are also seen the increasing production trends except potato and pulses. On the other hand the fish and animal production are increasing from the previous times. This food availability condition of Bangladesh is improving day by day (Akanda, 2012).

Access to food: The access to food condition for the rice is decreased from 1995-96 to 2009-2010 but still it is more than the need. On the other hand though, the consumption trends for the wheat and other cereal crops increased but there are seen the gap between demand and food taken. The same situation is seen for the 
non-cereals crops, meat and milk. The fish and egg taking tendency have increased from the previous times and it is fulfilling the personal demand (Akanda, 2012). Though the food availability condition of Bangladesh is improving, but in present times the prices of food items are increasing. On the other hand climate change is creating an extra pressure on this.

ADAPTATION:IPCC defines adaptation as "Adjustment in natural or human systems in response to actual or expected climatic stimuli or their effects, which moderates harm or exploits beneficial opportunities" (IPCC Online, 2001). It involves learning to manage new risks and strengthening resilience in the face of change (FAO, 2008). Adaptation to climate change is therefore the process through which people reduce the negative effects of climate on their health and well-being and adjust their lifestyles to the new situation around them. "In a nutshell adaptation is being better prepared or adapting to climate change, not fighting it, but learning to live with it"(Pender, 2008). In countries where the majority of poor people depend on agricultural income, proposed climate change adaptation strategies center around increasing agricultural productivity and making agriculture, including livestock, fishery and forestry, less vulnerable to climate stress and shocks ( Ludi, 2009).Hence, the linkage between climate change and food sovereignty requires risk reduction focused strategies. It is essential to have climate adaptation planning in such a way that conserves and sustains the ecosystems and support the poor and ensures food security for the growing population (Masum and Hasan, 2009). It must, therefore, adapt itself to the changing circumstances. Adaptation requires assessment of vulnerability from the viewpoint of different disciplines, which then requires an integrated approach. Modern technological advances can play a vital role to choose the appropriate adaptive measures. One of the best ways to adapt to climate change is to involve people at the grass-root level. The people of Bangladesh are very enterprising and innovative. They have been living with disasters for a long, long time (Ali, 1999).

Adaptation Strategies: A handbook on methods for climate change impacts assessment and adaptation strategies has been developed by the UNEP. The handbook discusses the principles and strategies for adaptation (Pittock, 2009). These can be summarized in eight alternative but not exclusive strategies-

1. Bear Crop Losses: When potential loss of a standing crop is totally accepted by the growers, bearing crop losses is an adaptation option. It is however criticized that the option is rather theoretical, with limited applicability in Bangladesh. In practice, it is argued that, it is possible only when the cost of adaptation appears to be higher compared to the net crop loss (Ahmed and Schaerer, 2004). This strategy is very negligible and the developing countries are forced to follow it.

2. Share Losses: This involves a wider community in sharing the losses. In societies organized on a largescale, losses are shared through emergency relief, rehabilitation, and reconstruction paid by government funds or public appeals, or through private insurance (Pittock, 2009).

3. Modify the Threats to Crop Production: This appears to be the mostly practiced option in Bangladesh.Adequate precautionary measures might possibly modify the threats. Many such measures are technology-oriented and may require early investment for research and extension. Development of drought and/or salinity tolerant varieties, switching to alternative cropping patterns with respect to altered agroecological zones etc. could modify the threat to a significant extent (Ahmed and Schaerer, 2004).

4. Prevent Adverse Effects: Some measures might consider preventing the losses in agricultural production. Preventive measures are anticipatory and might require large-scale investments (Ahmed and Schaerer, 2004). But this measure can be rarely implemented in the context of Bangladesh.

5. Change Land Use: Where the threat or reality of climate change makes the continuation of an economic activity impossible or extremely risky, consideration can be given to changing the use (Pittock, 2009). In case it becomes extremely risky to continue agricultural activities under an altered climate scenario, an alternative land use might be considered as the next available option. If the suitability of Aus paddy in preKharif months (March-June) appears to be too low, the farmers should alter the land use and instead grow other suitable crops. However, such alterations should ideally lead to acceptable economic returns, optimizing social goods and services (Ahmed and Schaerer, 2004).

6. Change Location: Change of location entails relocation of agricultural activities in areas that are not likely to be adversely affected. For Bangladesh, this appears to be a theoretical approach. Here access to land resources per capita is already high and there is hardly any unproductive land. Relocation, therefore, might not be socially accepted. Opting for relocation may necessitate long-term planning involving the farmers, farming communities and local governments (Ahmed and Schaerer, 2004).

Different Types of Adaptation: Adaptation is a spontaneous way to cope up with changing situation for avoiding unexpected losses. There are different types of adaptation. Every type of adaptation type has the respective application in terms of the adverse impacts. 
1. Structural Adaptation: Structural adaptation means taking some structural measures to reduce the impacts of climate change. Structural adaptation is costly approach and not always applicable. For ensuring food security from the adverse impacts of climate change production of the food items have to be increased. For doing this job polders, sluice gate, barrage, rain water harvesting, etc. have to be constructed in the coastal area (Disaster Dictionary, 2009).

2. Non-Structural Adaptation: This adaptation type considers as the soft adaptation. Dissemination of the relevant information to the people, raising awareness among the people, etc is included in this type. Despite this migration from high risk area to the less risk area is also considered as the non- structural adaptation (Disaster Dictionary, 2009).

3. Anticipatory Adaptation: There is a proverb that" prevention is better than cure". This is the main theme of anticipatory adaptation. Sometime more aware community can take the initiatives to reduce adverse impacts of climate change before experiencing the consequences. This type of adaption is appropriate for the developing countries like as Bangladesh for lack of funding (Disaster Dictionary, 2009).

4. Reactive Adaptation: Post disaster adaptation means the reactive adaptation. Decisions are taken after observing the consequences of the disasters. This is the costly and time consuming adaptation. The affected sectors are identifier firstly than the proper steps are taken to ensure the food security from the climate change (Disaster Dictionary, 2009).

5. Autonomous and Planned Adaptation: In its 2007 report, FAO distinguished between autonomous (micro - farm level) and planned (macro - policy level) adaptation. Examples of autonomous adaptation to climate change include changes in sowing dates, production of different crop varieties or species, changes in the use of irrigation and water supply, changes in the use of other inputs or in farm management (e.g. fertilizer, tillage methods, and grain drying).

Planned adaptations are sector-wide changes in processes or systems to build climate resilience or to encourage shifts in resources to a more efficient use under climate change effects. Examples of planned adaptations include addressing changes in food insecurity, identification of vulnerabilities, reassessment of agricultural research priorities, strengthening of agriculture extension and communication systems, adjustments in commodity and trade policy, and increased training and education (FAO, 2007a).

Adaptation for maintaining food security: In addition to risk management, climate change also requires adaptive management that focuses on modifying behaviors over the medium-to-long term to cope with gradual changes in precipitation and temperature regimes. These modifications are likely to concern consumption patterns, health care, food and agricultural production practices, sources and use of energy, and livelihood strategies (FAO, 2008).

Strengthening resilience for all vulnerable people involves adopting practices that enable them to:

$>$ protect existing livelihood systems;

$>$ diversify their sources of food and income;

$>$ change their livelihood strategies;

$>$ migrate if there is no other option (FAO, 2008).

Adjusting consumption and responding to new health risks: Faced with rising prices and increased awareness of the environmental consequences of their food choices, consumers may modify their spending and eating habits. Environmentally conscious consumers may choose to change their food consumption patterns relying more on local produce with a lower carbon footprint, and reducing their consumption of grain-fed livestock with large requirements for increasingly scarce land and water resources. Examples of possible changes in food consumption patterns include:

$>$ shift in staple food preferences;

$>$ shift away from grain-fed livestock products;

$>$ increase consumption of new food items;

$>$ reduce consumption of wild foods;

$>$ reduce quantities and/or variety of food consumed.

As well as adjusting consumption patterns to obtain a sufficient quantity of food, it will also be necessary to make adjustments to maintain dietary quality. This could involve:

$>$ protecting biodiversity and exploiting wild foods;

$>$ promoting urban and school gardens;

$>$ increasing use of dry cooking methods to conserve water;

$>$ promoting energy-efficient and hygienic food preparation practices;

$>$ teaching good eating habits to reduce malnutrition and diet-related diseases (FAO, 2008).

Increased incidence of water-borne diseases in flood-prone areas, change in disease vectors and habitats for existing diseases, and emergence of new diseases will pose new risks for food security, food safety 
and human health. Vector changes are a virtual certainty for pests and diseases that flourish only at specific temperatures and under specific humidity and water irrigation management regimes. This will expose crops, livestock, fish and humans to new risks to which they have not yet adapted. It will also place new pressures on care givers within the home, who are often women, and challenge health care institutions to respond to new parameters. Where such vector changes can be predicted, varieties and breeds that are resistant to the likely new arrivals can be introduced as an adaptive measure (FAO, 2008). Food security is the socio-economic term. People cannot depend on any single sector from which they can meet their food demand. If any livelihood sector is affected due to climate change so the food insecurity condition is experienced. There are some sectors which are now experiencing the negative consequences due to climate change. So sector wise adaptation is mandatory.

Adaptation in Agriculture: Agriculture should be in the frontline for adaptation priorities, given its natural vulnerability to climate and its crucial importance for food security and livelihood protection in developing countries. However, the local nature of adaptation actions and benefits raises issues about the local capacity for coping and implementation. These concerns are heightened because those most vulnerable to the effects of climate change, or the potential beneficiaries from adaptation, often lack the capacity and finance needed. Considerable efforts will be required to prepare developing countries in particular to deal with climate related impacts on agriculture (FAO, 2007a).Despite being agriculture is highly vulnerable to climate change; very little efforts have so far been made to understand potential of agricultural adaptation in Bangladesh. In order to enable the agriculture sector to adapt to adverse impacts of climate change, different steps should be promoted to enable it play its role in a context of agriculture as well as food security and general economic crisis. Various adaptations to climate change for agriculture as well as food security of Bangladesh is identified through review of various documents and consultations.

Table 14: highlights a few agricultural adaptations, according to the IPCC typology of Adaptation. (Strategic Approaches Considered for Agricultural Adaptation for RVCC Project).

\begin{tabular}{|c|c|c|}
\hline Strategy & Measure & Brief Description of Measure \\
\hline \multicolumn{3}{|c|}{ Household level strategies in agriculture (crop, fishery, agro-forestry, \& livestock) } \\
\hline \multirow[t]{5}{*}{$\begin{array}{l}\text { Increase food } \\
\text { through agriculture }\end{array}$} & $\begin{array}{l}\text { Drought tolerant } \\
\text { crops/vegetables }\end{array}$ & $\begin{array}{l}\text { Introduction of drought tolerant crops such as groundnuts, watermelon, } \\
\text { etc. }\end{array}$ \\
\hline & Floating gardens & $\begin{array}{l}\text { Cultivation of vegetables on floating beds of water hyac inth } \\
\text { (hydroponics) }\end{array}$ \\
\hline & Low-cost irrigation & $\begin{array}{l}\text { Demonstration of treadle pump and other simple technologies for } \\
\text { irrigation }\end{array}$ \\
\hline & Homestead gardening & $\begin{array}{l}\text { Cultivation of vegetables and fruits on homestead plots for } \\
\text { consumption and market }\end{array}$ \\
\hline & Sal ine tolerant non-rice crops & $\begin{array}{l}\text { Introduction of saline tolerant varieties of chili, mustard, maize and } \\
\text { potato }\end{array}$ \\
\hline \multirow{15}{*}{$\begin{array}{l}\text { Increase income } \\
\text { through alternative } \\
\text { livel ihoods }\end{array}$} & Embankment cropping & $\begin{array}{l}\text { Cultivation of beans, gourds, okra \& other vegetables on embankments } \\
\text { surrounding prawn ghers (ponds) }\end{array}$ \\
\hline & Integrated farming systems & $\begin{array}{l}\text { Using small area of land, small water body, and surrounding } \\
\text { embankments to produce rice, fish and vegetables }\end{array}$ \\
\hline & Cage aquaculture & $\begin{array}{l}\text { Small-scale fish farming in cages, implemented in household ponds or } \\
\text { common water bodies }\end{array}$ \\
\hline & Prawn fish poly-culture & Prawn and fish culture in fresh-water ghers (ponds) \\
\hline & Shrimp fish poly-culture & Shrimp and fish culture in salt-water ghers (ponds) \\
\hline & Cattle rearing & Raising cattle for consumption and market \\
\hline & Poultry rear ing & $\begin{array}{l}\text { Raising chickens to produce meat and eggs for consumption and } \\
\text { market }\end{array}$ \\
\hline & Crab fattening & $\begin{array}{l}\text { Collection, rearing and feeding of crabs for a period of } 15 \text { days to } \\
\text { increase their market value }\end{array}$ \\
\hline & Duck rearing & Raising ducks to produce meat and eggs for consumption and market \\
\hline & Goat rearing & Raising goats for consumption and market \\
\hline & Pig rearing & Raising pigs for consumption and market \\
\hline & Apiculture \& honey processing & Beekeeping and processing of honey for market \\
\hline & $\begin{array}{l}\text { Nursery \& homestead } \\
\text { afforestation }\end{array}$ & $\begin{array}{l}\text { Establishment of community nurseries and distribution (with handling } \\
\text { instructions) of indigenous varieties of tree saplings (mango, coconut, } \\
\text { sofeda, korai, guava, mehaguni, neem, kewra, etc.) to beneficiaries for } \\
\text { homestead planting }\end{array}$ \\
\hline & Saline tolerant tree plantation & $\begin{array}{l}\text { Planting of saline tolerant fruit and timber trees for longer term income } \\
\text { generation }\end{array}$ \\
\hline & Mele (reed) cultivation & $\begin{array}{l}\text { Cultivation of reeds that are used to produce mats that are widely used } \\
\text { for sitting and sleeping on }\end{array}$ \\
\hline
\end{tabular}

(Source: Environmental compendium, 2009)

Diversification of crop agriculture is a key approach in addressing climate change, but requires research on appropriate varieties for the new physical, social and climatic conditions. Diversification should be coupled with the revitalization of local varieties that have a greater resilience to extreme climate events.

$>$ Invention of short time harvested rice to avoid the negative impacts of natural hazards.

$>$ Household and community assetscan be reinforced through alternative livelihood options such as homestead gardening, horticulture, floating gardens and handicraft production. Increasing assets and diversifying livelihood options are key components in ensuring that communities are able to adapt to meet the challenges that climate change brings.

$>$ Information on pest control and methods to protect winter vegetables from extreme cold and fog needs to be disseminated. 
$>$ Seed banks can be established to ensure that varieties remain available following disaster periods.

$>$ Awareness raising on strategies for building adaptive capacity and the implications of climate change amongst local level non-government organizations, agricultural extension officers, block supervisor of Department of Agricultural Extension (DAE), and farmers.

$>$ Invention of saline tolerant crop veritysaline tolerant variety of crop must be invented for adaptation in agriculture.

$>$ Increasing fresh water holding capacityfresh water is very essential for the agricultural production. So the rain water holding capacity must be increased (Rahman and Mallick, 2010).

$>$ Farmers can use ash in the field to keep the soil warm during winter.

$>$ Farmers can adopt some innovative practices (viz. zero tillage, sorjan system, etc.) in flood prone and salinity/tidal surge areas.

$>$ Documentation, motivation, training \& dissemination of new adoptive technologies by the farmers.

$>$ Development of linkage with GO/NGOs and private sectors (Rahman et al, undated).

Adaptation in Fisheries: Fisheries are another livelihood option to the people of coastal area. People of coastal area mainly take animal protein from the fishes. So this sector has a great contribution on the food security. The following measures can be taken for adaptation in fisheries.

$>$ Raising pond embankment should be introduced for the protection of unexpected water intrusion.

$>$ Pond fencing by net should be introduced for protection of fishes to fly away.

$>$ Awareness and precaution should be ensured among the people.

$>$ Enhancement of fish production through rehabilitation of fish production and establishment of fish sanctuary increased aquaculture production

$>$ Aquatic vegetation shelter in ponds should be introduced for the better habitation to fishes.

$>$ Agitation of surface water for ensuring proper growth of fishes.

$>$ Advance fishes selling before the rough season coming.

$>$ Re-digging pond deeply for ensuring better habitation

$>$ Preparing water reservoir to provide water in ponds during dry seasons.

$>$ Introduction of cage fishing.

$>$ Introduction of saline tolerant fish culture where the salinity is major problem.

$>$ Binding boats and nets with trees during disasters.

$>$ Introduction of integrated fishing mechanisms.

$>$ Giving emphasis on further scientific research in fisheries.

$>$ Taking proper and pragmatic steps to conserve the local fish species from extinction.

$>$ Avoiding catching the breeding fishes.

$>$ Changing fish species ( Rahman et al, undated).

Adaptation in Livestock: In recent times various types of changing situation are observing in this sector. So, appropriate steps can protect this sector from the unexpected consequence.

$>$ Increase the grazing lands for the livestock.

$>$ Ensuring the alternate food for the livestock.

$>$ Giving the proper habitation facilities to livestock.

$>$ Inventing the genetically modified livestock species especially for the saline affected areas.

$>$ Integrated livestock management should be introduced.

$>$ Transfer of small ruminant and poultry from flood and cyclone affected areas to high land

$>$ Emergency recovery, restoration \& response with long term restoration should be ensured

$>$ Cold water spraying on the shed during high temperature.

$>$ Use of preventive medicine for disease prevention and curative measures

$>$ Advance food preservation

$>$ Preparing raised land for habitation

$>$ Introduction of Salinity tolerant grass or fodder ( Rahman et al, undated).

Steps Facilitating Adaptation at National and Local Level:

$>$ Strengthen policies for food security, forests, manage disasters and infrastructure development

$>$ Appropriate allocation of funds for National Development Programme Implementation

$>$ Step up observation systems \& technology development and dissemination

$>$ Strengthen Institutional mechanisms as instruments of adaptation at local level

$>$ Arrangement of funds for adaptation

$>$ Mainstream climate change concerns and hence adaptation in the planning process

$>$ Consider Development as one of the pathways for adaptation (Chattopadhyay, 2008). 
The impacts of climate change are not severely observed in our country but it has a great potentiality for the future. So, adaptation is a great strategy to adjust with the climate change. As Bangladesh is developing country so Bangladesh should give more emphasis on the appropriate adaptation measures to combat the climate change for ensuring food security.

Adaptation in agriculture due to climate change: As agricultural sector is most vulnerable sector due to impacts of climate change so adaptive measures are essential to combat adverse situations. Govt. has taken many measures in agricultural sector. For these measures the impacts of climate change are not severely felt. In some parts, production of the crops is increasing for these adaptive measures.

Most of the farmers about $43.9 \%$ are taking modern technology. $21.95 \%$ people are taking HYV seeds. Some parts of the people about $7.31 \%$ are taking saline tolerant variety etc. for the adaptation in agriculture. People are also taking the training about modern farming system to reduce the probable impacts of climate change.
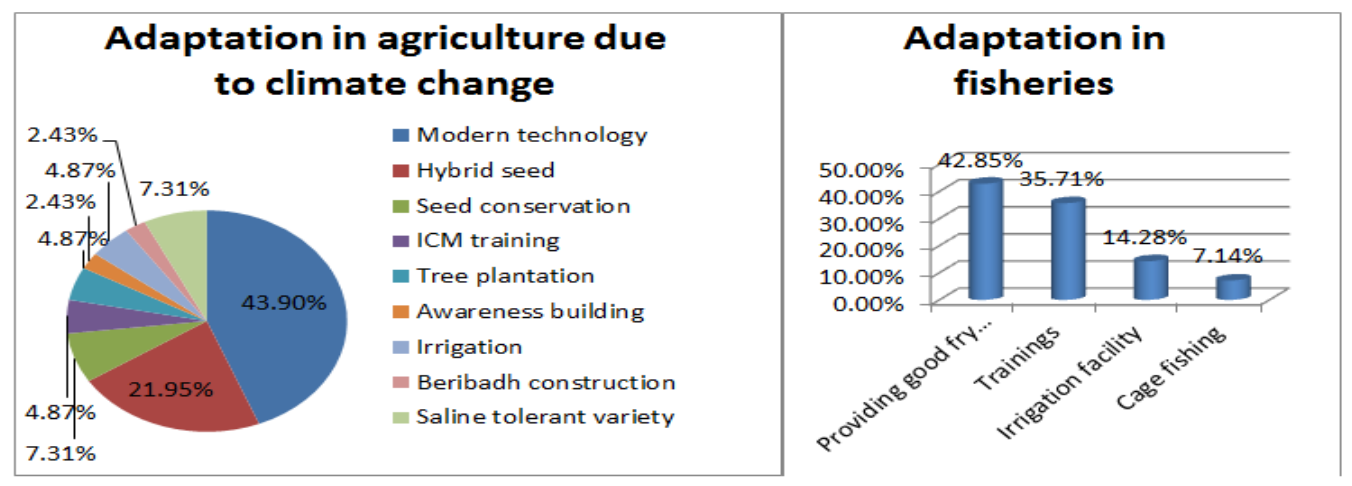

The people of Kalapara are taking different types of adaptive measures to combat climate change. The local fisheries offices are helping the affected people. In that area the fisheries training institute and a great number of hatcheries are seen. So the different saline tolerant fishing procedures are taking by people. Sometimes fishermen are taking training for good fish production.

From the primary data it can be said that production of different agricultural crops are increased with times though the people are experiencing the impacts of climate change. In recent times number of population is increasing rapidly so people are taking extra initiatives to increase the production. On the other hand different climate resilient technologies are now using by people so the production of crops are increasing. On the other hand the impacts of climate change in Kalapara are not extreme. From these situations it can be said that food production of the crops is improving. But food security is not only dependent on the food availability but also some other factors. Due to the global climate change the food supplies are hampering. Despite this for the frequent occurrence of disasters the situation becomes worse. The prices of the commodities are increasing and for this reason people are reducing their consumption. Ultimately the food security condition is degrading. For combating this situation Govt. should take some pragmatic steps to ensure the food security.

Map analysis: Map is an essential tool for geographical research and it is incomplete without map analysis. In this work different maps have been represented to indicate relevant information. Kalapara under the Patuakhali district selected for study which is very adjacent to the Bay of Bengal. The numbers of people of Kalapara are increasing day by day. This increasing number of people is creating extra pressure on food. In recent times there is seen the increasing trend of crop cultivation among farmers for fulfillment of their extra food for demand. So the food production trend of the study area is increasing. If we are to accept the Malthusian Theory regarding population growth and agriculture then very soon there will be a shortage of food. This imbalance situation will bring the extra pressure on the food security condition of study area. Climate change is a great concern to us. Many unexpected impacts are being experienced due to climate change.

In this section different agricultural maps are represented which are related to the food security of that study area. These maps are compared with the past 10 years situation, shows the changing pattern of different crop cultivation in the area at present.

Net Cultivated Area: In 1996 three unions viz. Dhankhali, Nilgang, and Mithaganj had more net cultivated area. In Dulashar there was less cultivated land because most people of this union were fishermen during that time. In Tiakhali there was about 6000 acres of net cultivated land. This area was comparatively less than the others unions, because this is a town area. For this reason most of the people were dependent on non agricultural 


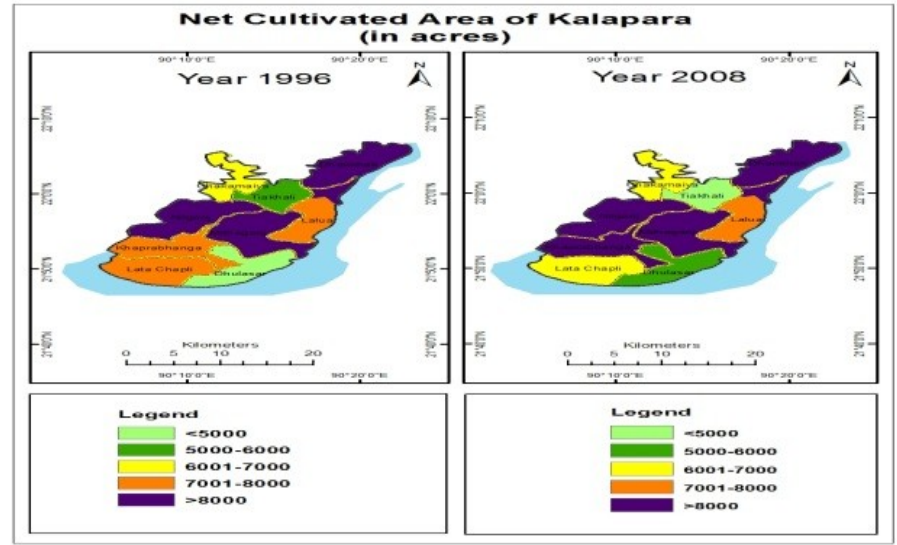

Map 2: Net cultivated area of Kalapara

activities. In 2008 three union viz. Dhankhali, Nilgang, Mithaganj and Khaprabhanga have more net cultivated area. In Dulashar and Tiakhali there is less than 5000 acres of net cultivated land because most people of these union are fishermen and also engaged in non-agricultural activities. Land area is decreased in Lata Chapli union. The people of this union have taken fishing and tertiary economic activities instead of cultivation because of KUAKATA sea beach. But the cultivated land is static in Chakamaiya and Lalua union with time. Finally it can be said the total net cultivated are of the study area is increased in present times than the previous decades.

Area under HYV Aman: In 1996 Khaprabhanga and Dhulsar there were less than 500 acres of land under HYV aman cultivation. In Dhankhali and Lalua there were amon cultivation land more than 500 acres and less than 1000 acres. Chakamaiya Tiakhali had aman cultivated land between 1500-2000 acres in these range. In Nilganj, and Mithaganj there had more

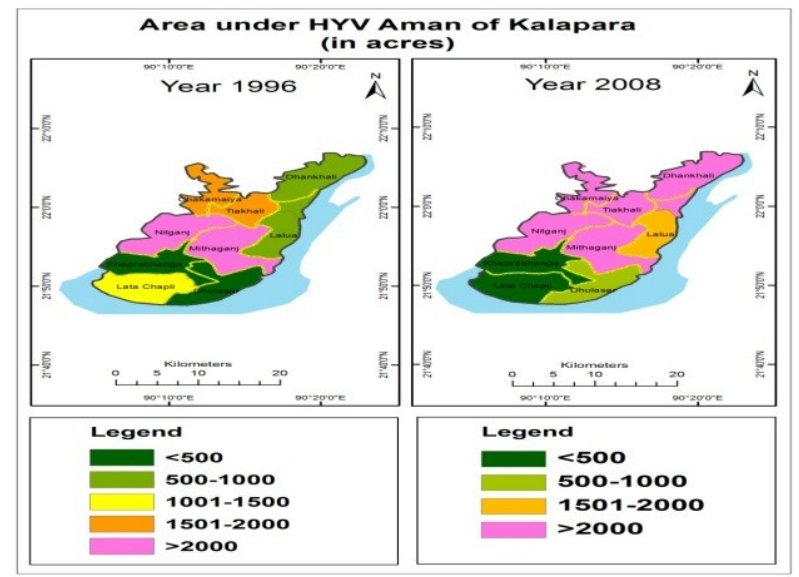

Map 3: Area under HYV Aman of Kalapara.

than 2000 acres of land. From this feature it can be said that last two unions were more favorable for Aman rice cultivation because these area were less flooded and with less salinity problem compared with others. In 2008 Lata Chapli and Khaprabhanga there are cultivated land less than 500 acres. In Tiakhali, Nilganj, Mithaganj, Dhankhali, Chakamaiya in these area the Aman cultivated area are increased with times. So the overall Aman production is increased in Kalapara compared with past. It's a positive indication to the food security condition of the people.

Area under HYV Aus: Cultivation of HYV aus was prominent in Dhankhali and Chakamaiya unions in the year of 1996. But after 12 years aus cultivation is decreased in Chakamaiya and increased in Lalua union. And in other unions there is seen the static aus cultivation. 


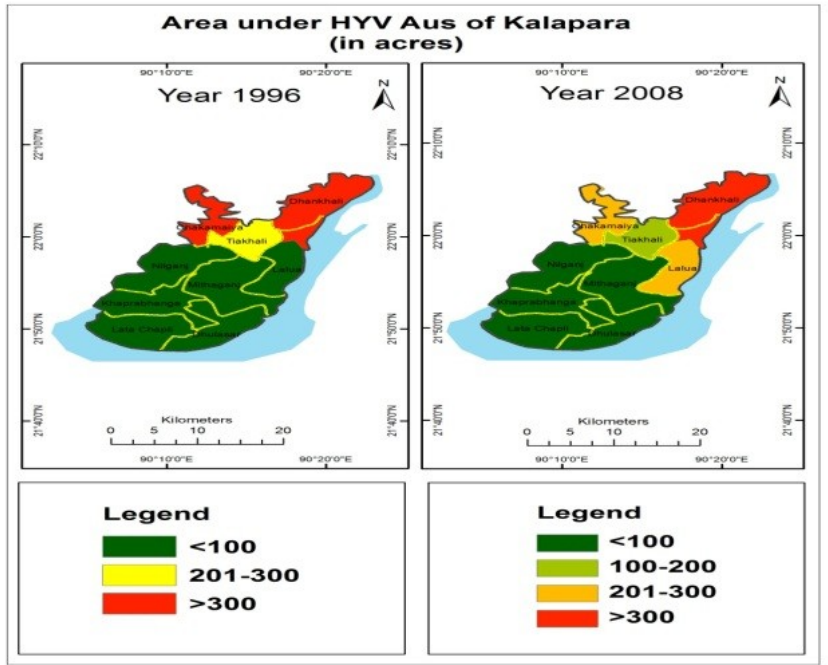

Map 4: Area under HYV Aus of Kalapara

Area under HYV Boro: In 1996 boro rice was cultivated very slightly in Dhankhali, union. On the other hand, other unions were totally barren about boro rice cultivation. In 2008 boro rice is cultivated almost all of the unions viz. Nilganj, Mithaganj, Dhankhali, Lalua and Lata Chapli. So, the area under boro cultivation is increasing rapidly in Kalapara. As farmers are getting better production from the crop so they are frequently cultivating the boro crops. This crop rarely face natural disasters like as cyclone, floods etc for its cropping season.

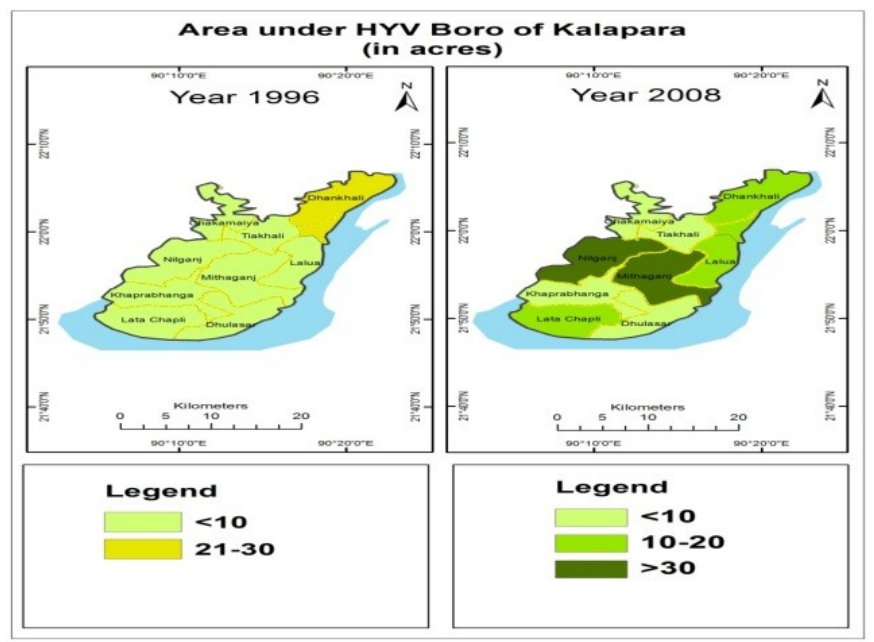

Map 5: Area under HYV Boro of Kalapara

Area under Local Paddy: In 1996 three unions had more than 8000 acres of land under local paddy cultivation. But in 2008 there are only one union more than 8000 acres of land under local paddy cultivation. So from this situation it can be said that the trend of local paddy cultivation is decreasing compared with last decade. As the output of the crops are not satisfactory to meet the demand of increasing number of population so people are not interested to cultivate this rice in any longer. On the other hand these crops are very susceptible to the climate change situation like as salinity, pest attack etc. So people are cultivating HYV crops instead of local crops. 


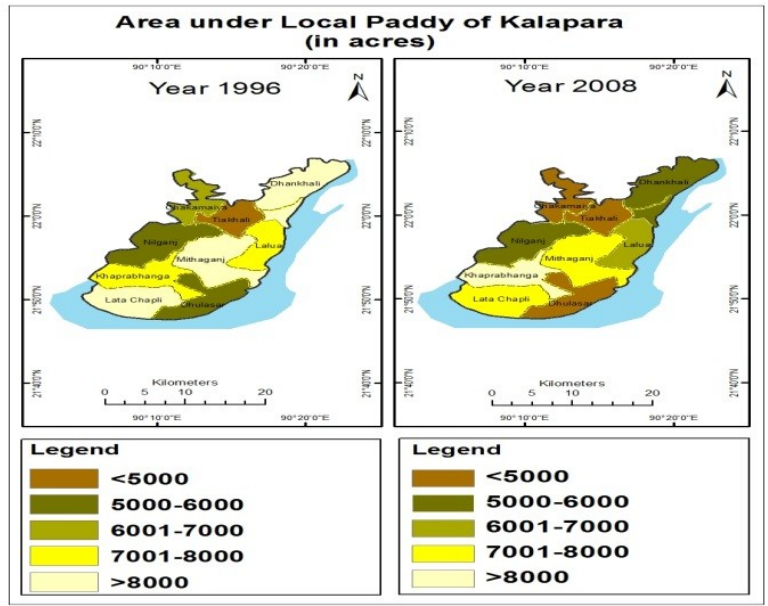

Map 6: Area under Local Paddy of Kalapara

Area under Vegetable cultivation: In 1996 more than 200 acres of land was cultivated for vegetable in Chakamaiya but other unions were comparatively less cultivated than that Chakamaiya. In 2008 there are six unions where more than 200 acres of land are being cultivated under vegetables. So the trends of vegetables cultivation are increasing rapidly. In present times the price of daily essential commodities is increasing so people are trying to meet their daily vegetable demand by cultivating barren lands and homestead area. In this way the production of the vegetables is also increasing. But due to climate change the production of these vegetable cannot reach in optimum range of harvest. On the other hand in Nilgang and Mithaganj unions there is seen the some climate resilient vegetable cultivation under the different projects of the Agricultural extension offices.

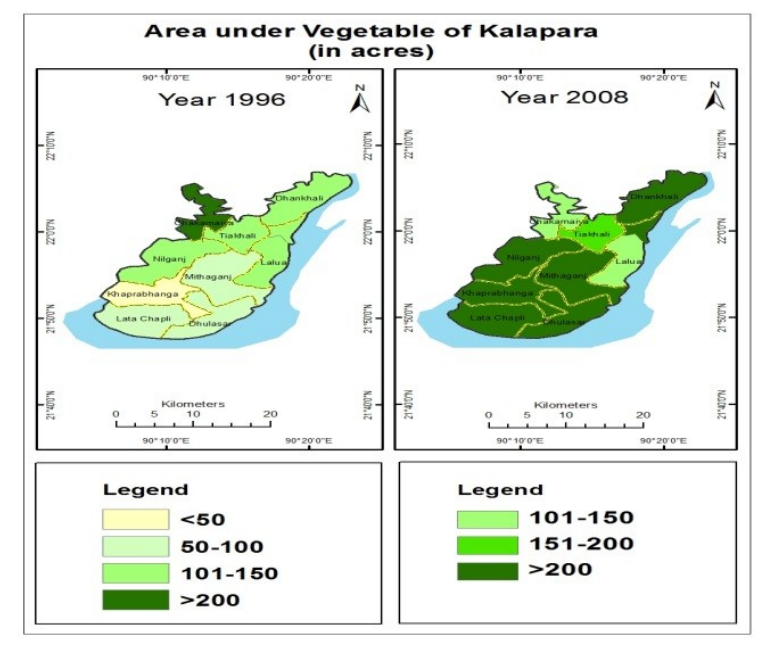

Map 7: Area under Vegetable cultivation of Kalapara

Number of Cattle: According to the agricultural census 1996, in 3 unions of Kalapara where cattle population were between 6000-7000 in this range. On the other hand there were 4 unions where were more than 7000 cattle population.

But according to the agricultural census 2008, in 5 unions where are cattle populations more than 8000 . From that observation it can be said that number of cattle population is increasing with times. These scenarios are also a good indication about food security condition. But in present times cattle are suffering from various problems viz. shortage of food, habitation problem, disease problems etc. due to climate change. The milk production and meat production are also hampering due to this causes. On the other hand the prices of meat and milk are also increasing due to higher demand and shortages of production. So finally the food security condition is also threatened. 


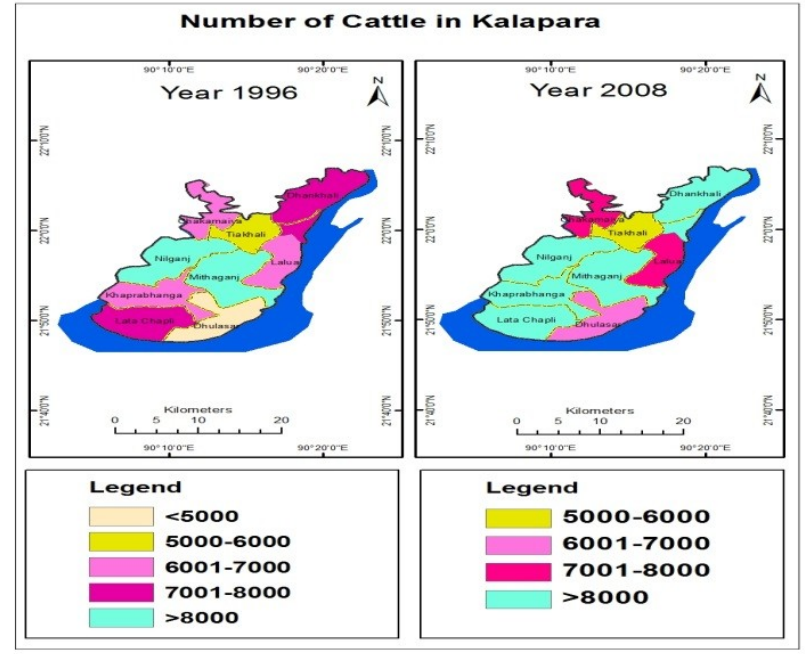

Map 8: Number of Cattle of Kalapara

Agricultural labor household: According to the agricultural census 1996, there were maximum 6 unions which had the agricultural labor household 1500-2000 in this range. But in 2008 there are 7 unions which have more than 1500 number of household labor. As the population of the study area is increasing so the number of labor households is also increasing. This situation indicates the worse economic condition of people for various reasons.

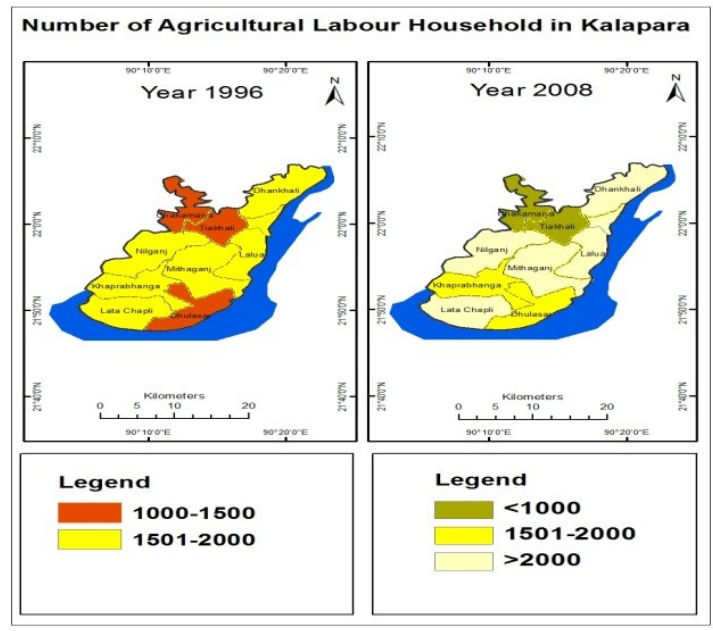

Map 9: Agricultural labor household of Kalapara

From the map analysis it can be clearly said that the production of the HYV crops are increased in the study area. But in the mean time the production of the local rice is decreased. Though the climate change impacts are observing in the study are but it is not as severe as assumed. On the other hand people are becoming more aware about the adaptation to climate change by taking different initiatives by the help of Govt. and NGOs. So the better production of the crops is good for the food availability. But this food availability is hampered due to the action of natural disaster viz. cyclone; flood etc. Despite this for climate change these natural disasters are frequently occurring in the area so the food security is threatened.

Photographic Analysis: Photographs are very important tools for representing the existing facts in any area. A real picture is much better than many explanations. Readers can easily understand about anything by observing any relevant photographs. Ancient people represented much important information to the next generation by paintings, photographs etc. In recent times photographs are earnestly using in the geographical research. In this chapter some of the relevant photographs are added to represent essential information about climate change and food security condition of Kalapara according to the objectives. 


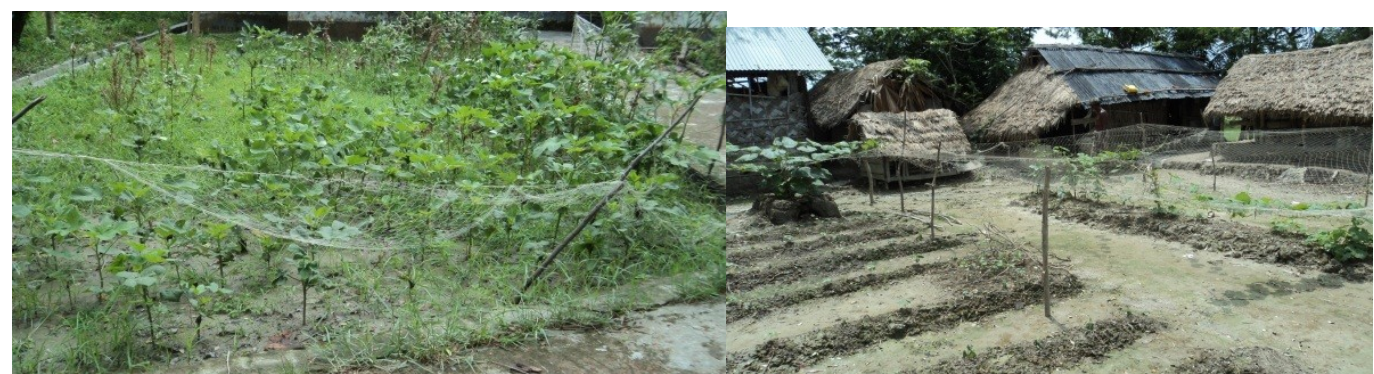

Picture 1: Homestead gardening.

In Kalapara people are being used their yards for the vegetation cultivation. This cultivation tendency is increasing in present times. As the price of essential commodities is increasing so, they are trying to meet their daily demand from the surrounding environment.

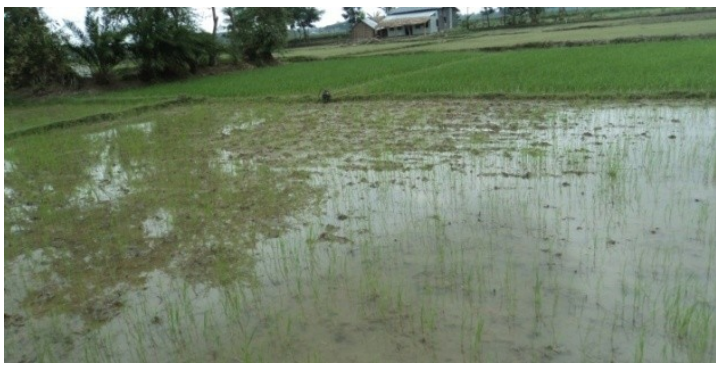

Picture 2: Paddy field of transplanted Aman

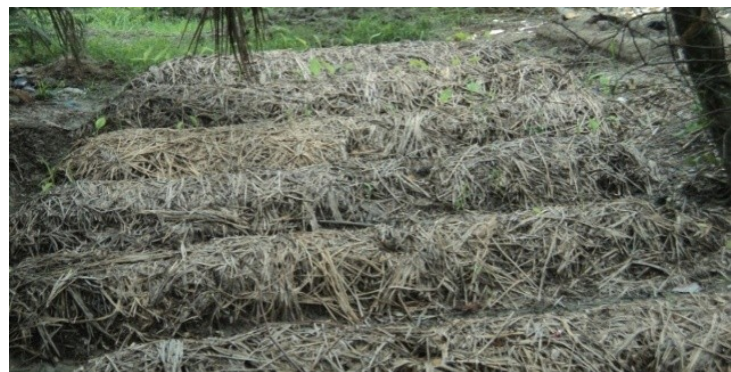

Picture 3: Seed- bed for turmeric cultivation

During the field survey it was observed that people are very much interested about the rice cultivation. They are intensively using their agricultural land for getting the better harvest. Different types of fertilizers, insecticides, pesticides, and other modern technology are using by the farmers. For this reason the crop production is increasing in present times. On the other hand for using these types of modern technology on the agricultural lands costing of production is increasing.
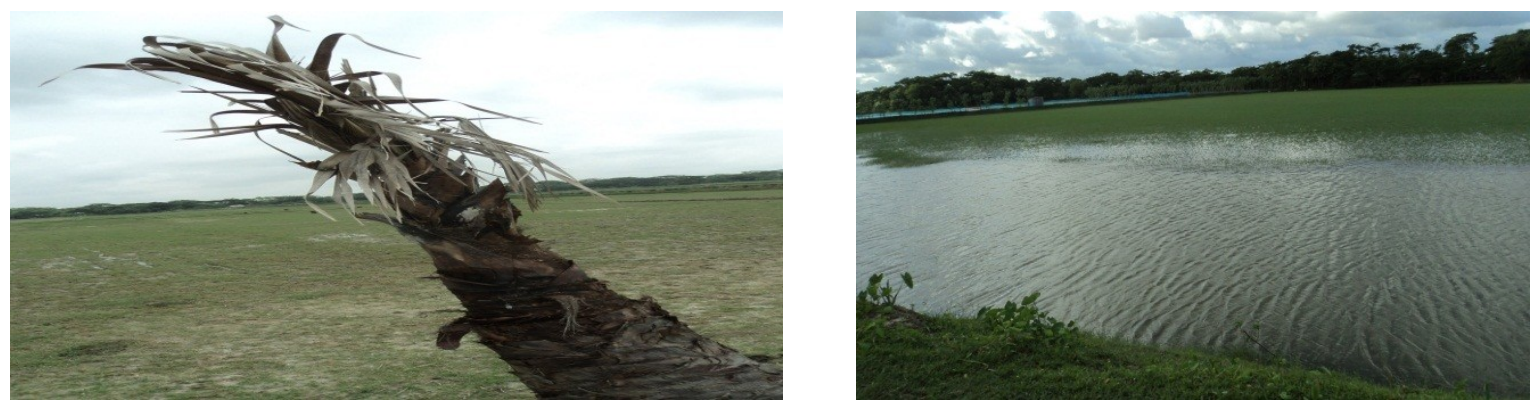

Picture 4: Death of a coconut tree for unfavorable condition \& Hampering the agricultural production due to unexpected inundation.

Due to climate change different types of negative consequences are observed in the study area. The agricultural lands are being submerged by the rain water or the river water for a long times. So, the agricultural production is being hampered.
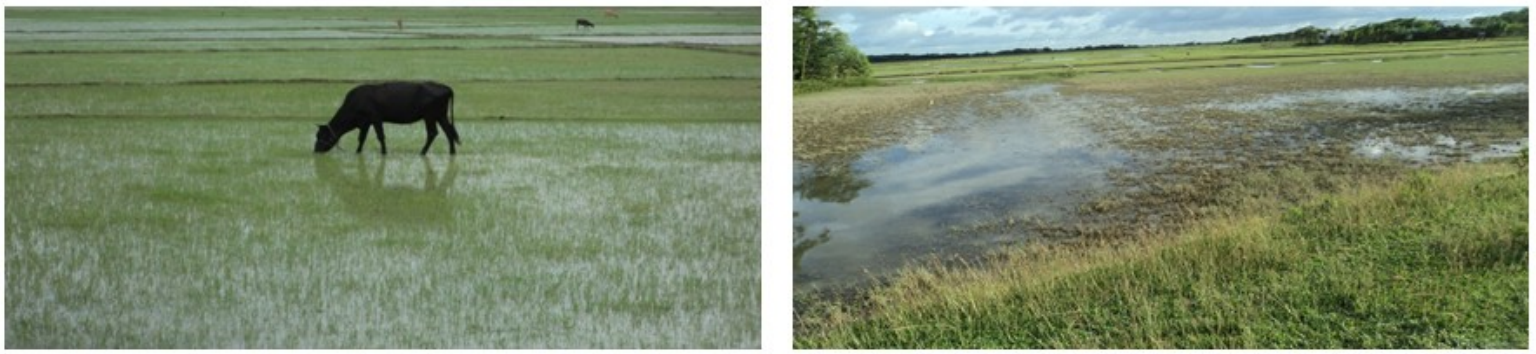

Picture 5: Hampering the cattle food due to inundation condition \& Fallow agricultural land 
Due to climate change different sectors are being hampered. In some parts of the study area mainly at the adjacent area of the Bay there were seen the salinity problems. On the other hand different unions were experiencing the inundation condition for the unexpected rainfall. So the agricultural production, as well as cattle population was suffering for the food scarcity.
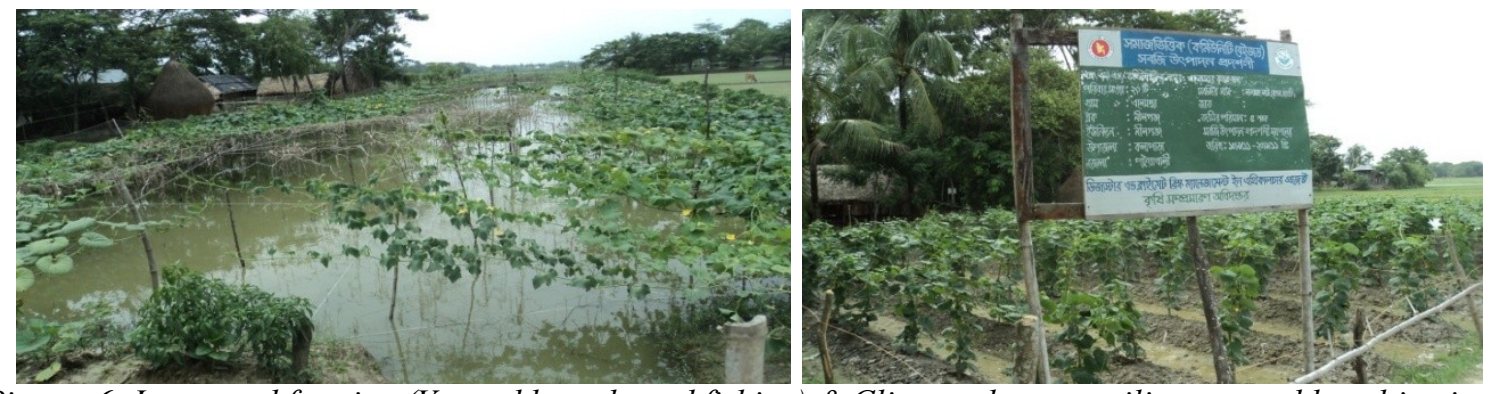

Picture 6: Integrated farming (Vegetable and pond fishing) \& Climate change resilient vegetable cultivation.

As climate change is a certain fate for the people and the Bangladesh is the worst victim of this anthropogenic climate change so, public level to the private level everyone is trying to reduce the impacts of climate change. In study area it was observed that Department of Agricultural Extension (DAE) and other NGOs are trying to transfer the technology to the climate change victim families. Despite these some other families are taking the concept of integrated farming. For these reasons the agricultural production is increasing in the climate change situation. These are the good indication for adaptation strategies.
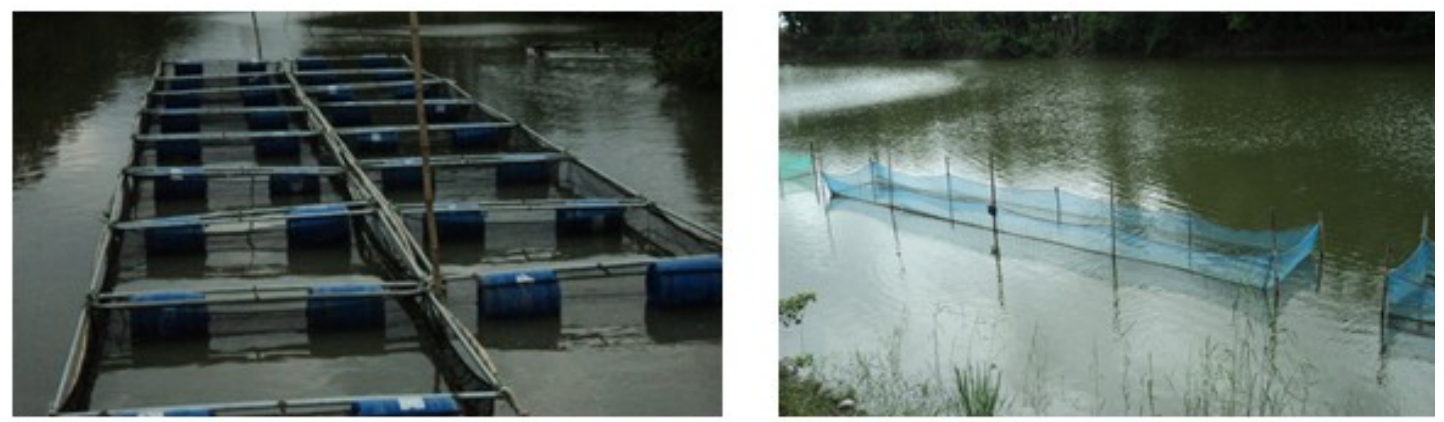

Picture 7: Cage fishing in Kalapara \& New saline tolerant fish fry production.

Adaptation is also observed in the fisheries sectors of Kalapara. In that area there were many fry breeding Hatcheries. These hatcheries are trying to increase the production of culture fishing rather than captured fishing. Some people of that area are being tried to take the new technology for fish production. Cage fishing is one of the best ways for the cultured fishing during the disaster period. For taking these types of initiatives the production of fish is increasing with time.

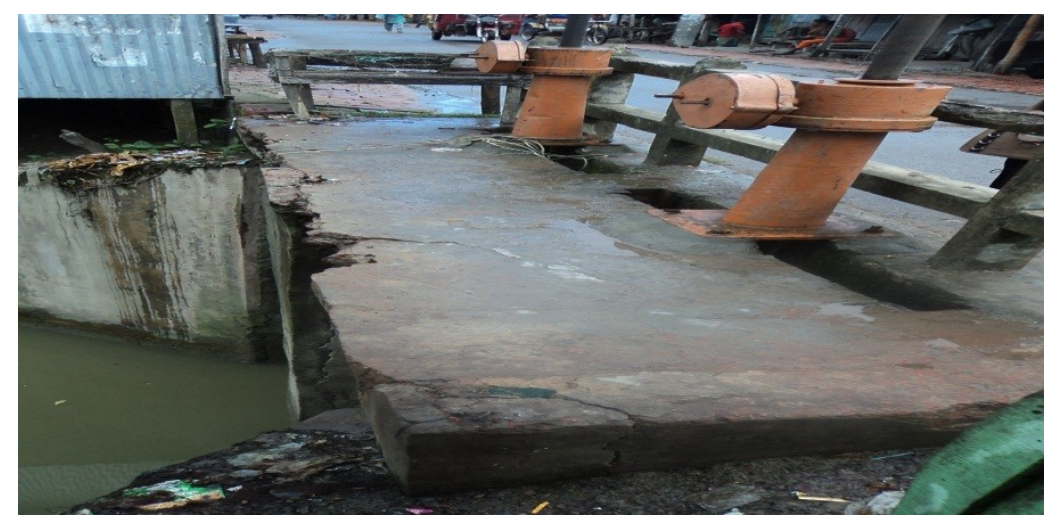

Picture 8: Sluice gate for controlling the saline water intrusion.

As salinity is a great problem to the study area so there are many sluice gates for controlling the saline water intrusion to the agricultural lands. These types of initiatives are also good for the agriculture as well as food security. 

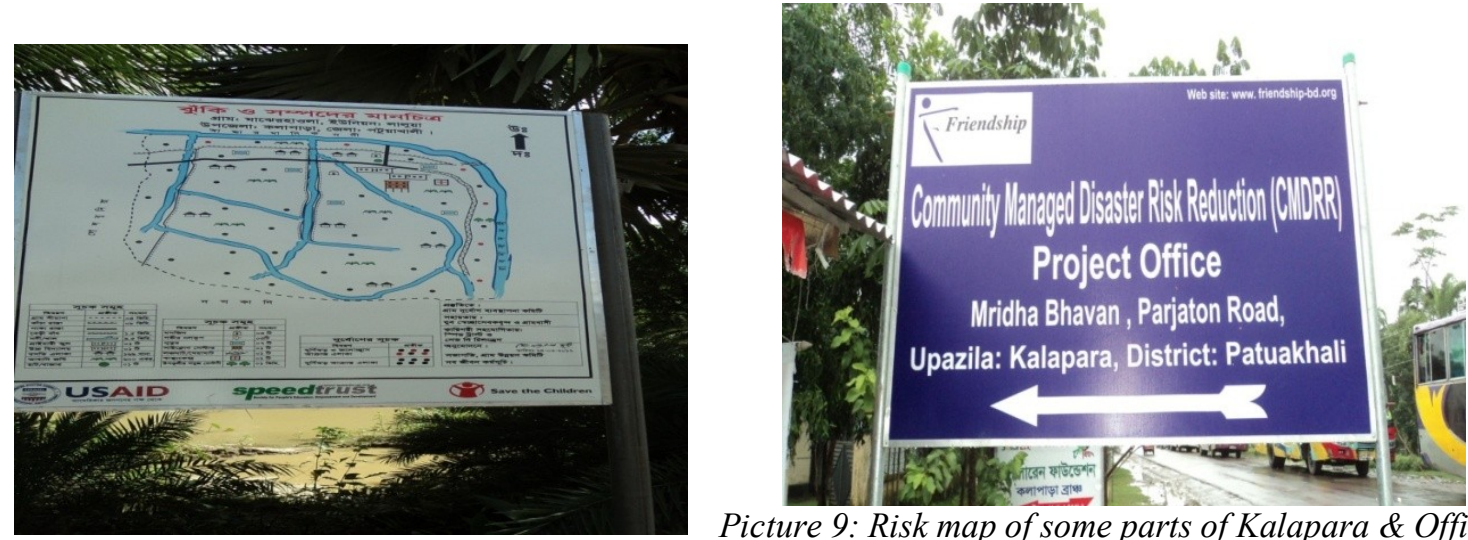

Picture 9: Risk map of some parts of Kalapara \& Office

of Community Managed Disaster Risk Reduction.

In study area there were observed the active function of different NGOs. They were trying to help the people from the different unexpected consequences. Finally by analyzing the different photographs it can be said that climate change consequences are very clear in the study area. But for taking proper pragmatic steps by the Govt. and NGOs the condition of the people are improving.

\section{Recommendation And Conclusion}

Recommendations: Climate change is a long time process. From the very ancient times the climate of the globe was continuously changing. Prevention of climate change is not possible. As the climate system is not dramatically changed so the impacts of climate change on food security is not severely observed. But this climate change has enough potentiality to hamper the food security. Whatever the impacts of climate change on food security but people are at bay due to this climate change. At any rate the observed impacts of climate change must be minimized. So this is an acid test for the future survival of people. For the climate change coastal communities are mainly victimized. Their livelihood is at stake for this climate change. This is a concerning matter for us. Proper initiatives have to be taken to reduce the sufferings of that vulnerable community. Despite this mitigation of climate change is not always feasible for third world countries like as Bangladesh. So finally the adaptation or adjustment is the appropriate solution for the country. Before taking the adaptation policies different environmental, socio-economic etc. aspects have to be considered, so that initiatives will be pragmatic. Following aspects should be considered for reducing the impacts of climate change to ensure the food security.

\section{Governments Initiatives-}

$>$ Proper information about the climate change has to be provided to the people.

$>$ Different social safety net programs (Relief, Food for work, Money for work, VGD, VGF, OMS, NS etc.) have to be started on the affected areas.

$>$ Monitoring the markets for controlling the price hikes.

> Proper structural measures like as cyclone shelter, polder, embankment etc. have to be constructed.

$>$ Soft lone among the affected people has to be distributed.

$>$ Alternate livelihoods have to be introduced which will not be affected due to climate change.

$>$ Govt. has to be patronized for further research in climate change, so that new knowledge can be easily implemented in future.

$>$ Govt. should strengthen the foreign policy to take the compensation from the developed countries that are mainly responsible for this unexpected climate change.

$>$ Govt. should introduce the climate fund under the supervision of Environment and forestry ministry to distribute the money among the climate vulnerable groups.

$>$ Some initiatives can be taken against the rapid $\mathrm{CO} 2$ emission rate around the world by negotiating with the world leaders.

$>$ Maintaining the good relationship among the other countries to ensure essential and emergency food imports.

$>$ Taking the proper steps to increase the food production of the country.

$>$ Population controlling is also essential to ensure the food security.

$>$ Encouraging the people to take green economy, green energy, green technology etc.

$>$ Initiating the national food storage systems to tackle the food shortage situation in an adverse time.

$>$ Increasing capacity building of the Climate Change and Food Security relevant ministries, departments, institutions and so on. 
> Forming the "Climate Change Advisory Groups" (CCAG) by including the experts, professionals etc. people to take the pragmatic and proper decision about the climate change related issues.

$>$ Forming the "Climate Change Parliamentary Committee" (CCPC) to ensure the logistic support to the Advisory groups.

$>$ Providing the insurance facilities to the affected communities.

$>$ Developing the communication facilities of the study areas to ensure food availability during disaster period.

$>$ Providing alternative livelihood facilities to the affected people to increase their income level.

\section{NGOs Initiatives-}

$>$ NGOs can launch the climate change centric programs and projects.

$>$ They can help the Govt. in awareness programs among the people.

$>$ Giving donation among the climate change affected communities.

$>$ Different nutrition campaigns and programs can be launched by them to ensure the food security.

$>$ Convincing the donor agencies to provide more money to the affected people in different sectors.

Personal or Family level initiatives-

$>$ People have to be more aware about climate change and food security issues. For this reasons the proper education must be needed.

$>$ Identifying their existing problems due to climate change.

$>$ Taking traditional and autonomous adaptation to tackle the existing problems.

$>$ Taking the proper training from agricultural extension services to increase the crop production.

$>$ Social or Community based food storage systems are necessary to ensure food security of that particular location.

$>$ Ensuring the livelihood variation to earn more money during the disaster.

\section{Conclusion}

Though climate change is an alarming situation for the people but impacts of climate change on the food security is not as severe as assumed. From this study it was seen the production of the different crops are increasing in Kalapara. This situation is seen due to the awareness rising among the people about climate change. Despite this the cultivation area of the crops is also increased. This is positive news for us. Though the production of crops is increased but the food security of the people is degraded. There are so many causes behind this reason. The higher production costing, higher commodity prices, higher number of population, inflation of the money, frequent natural disasters etc. are playing the negative roles to ensure the food security. Not only Govt. but also all of the people should take proper steps to ensure the food security.

\section{Acknowledgements}

At first the authors would like to express his praise to almighty ALLAH that the thesis was completed within perfect time. The authors expresses the profound gratitude, indebtedness and heartiest thanks to the honourable teacher DR. NASREEN AHMAD, Professor, Department of Geography and Environment, University of Dhaka, Bangladesh, for her valuable and patient advise, sympathetic assistance, constant encouragement, guidance, co-operation, kin interest, contribution to new ideas and supervision of all stages of this work. The authors tender his regards and profound complement to all the respective teachers of Department of Geography and Environment, University of Dhaka for the valuable suggestions and esteemed co-operations at different stages of the research. The authors thankfully acknowledge the intensive help of the Bangladesh Bureau of Statistics (BBS), Weather Station of Khepupara, UNO Office of Kalapara, Agricultural Office of Kalapara for their kind help with many information and ideas and give organizational support in completing the research

Finally authors like to express his appreciation and heartily thanks to others who have directly or indirectly helped him for this exclusive work.

\section{Census}

\section{References}

[1]. BBS, 2001, 1991, 1981. Population Census. Bangladesh Bureau of Statistics. Ministry of Planning. Government of Bangladesh. Dhaka.

[2]. BBS, 1983-84, 1996, 2008. Census of Agriculture Zilla Series, Patuakhali. Bangladesh Bureau of Statistics. Ministry of Planning. Government of Bangladesh. Dhaka.

[3]. BBS, 1986-2010. Year Book of Agricultural Statistics. Bangladesh Bureau of Statistics. Ministry of Planning. Government of Bangladesh. Dhaka.

\section{Books}

[4]. Park, C., 2001. The Environment. $2^{\text {nd }}$ ed. Routledge Taylor \& Francis Group. London and New York.

[5]. Pittock, A. B., 2009. Climate change: The science, impacts and solutions. $2^{\text {nd }}$ ed. Collingwood: CSIRO.

[6]. Disaster Dictionary, 2009. Ministry of Food and Disaster Management. CDMP. Dhaka. 
[7]. Karim, Z., Hussain, S.G. and Ahmed. M., 1996. "Assessing impacts of climate variations on food grain production in Bangladesh." Water, Air, and Soil Pollution 92:53-62.

\section{Journal}

[8]. Ahmed, A. U., 2006. Bangladesh: Climate Change Impacts and Vulnerability. Climate Change Cell. Department of Environment. Dhaka

[9]. Ahmed, A.U. and Schaerer, C., 2004. 'Sustaining Livelihoods Opportunities for the Coastal Poor Under Climate Change: A Case Study from Bangladesh', In Anonymous (ed), Proceedings of Coastal Zone Asia Pacific, Brisbane, 7 -9 September.

[10]. Akanda, A. I., 2012. Agricultural growth verses food security and safe- food security. New Age. 25 June.

[11]. Ali, A., 1999. 'Climate change impacts and adaptation assessment in Bangladesh'. Space Research and Remote Sensing Organization (SPARRSO), Agargaon, Sher-e-Bangla Nagar, Dhaka. Vol. 12: 109-116.

[12]. Asaduzzaman. M., et al. 2010. "Investing in Crop Agriculture in Bangladesh for Higher Growth and Productivity, and Adaptation to Climate Change". Bangladesh Food Security Investment Forum. Dhaka.

[13]. Basak, J. K., Undated. "Climate Change Impacts on Rice Production in Bangladesh: Results from a Model". Unnayan Onneshan. Dhaka.

[14]. CARE International 2011. Climate Change Brief: Adaptation and Food Security.

[15]. Darwin, R., 2001. "Climate Change and Food Security". Agriculture Information Bulletin Number 765-8. USDA. Washington, DC.

[16]. FAO. 2008. Climate Change and Food Security: A Framework Document. Rome.

[17]. FAO. 1996. Rome Declaration and World Food Summit Plan of Action. Rome.

[18]. FAO. 2003b. World agriculture: Toward 2015/2030, Chapter 13. Rome, Earthscan.

[19]. FAO. 2007a. Adaptation to climate change in agriculture, forestry and fisheries: Perspective, framework and priorities. Report of the FAO Interdepartmental Working Group on Climate Change. Rome.

[20]. FAO. 2007f. National Programmes for Food Security: FAO's vision of a world without hunger. Rome.

[21]. Gunter, B. G., 2010. "The Impact of Development on $\mathrm{CO}_{2}$ Emission A Case Study for Bangladesh until 2050". Bangladesh Development Research Center. U.S.A.

[22]. Habib, A., Undated. "Climate Change: Bangladesh Perspective". Bangladesh Meteorological Department. Dhaka.

[23]. Huq, S., Ali, S.I. and Rahman, A.A, 1995. "Sea-level rise and Bangladesh: A preliminary analysis." Journal of Coastal Research Special Issue 14:44-53.

[24]. Islam, A. K. M. S., Undated. "Analyzing changes of temperature over Bangladesh due to global warming using historical data". Institute of Water and Flood Management. Bangladesh University of Engineering and Technology, Dhaka.

[25]. IPCC Online. 2001. Glossary of Terms used in the IPCC Third Assessment Report.

[26]. IPCC, 2007. Climate Change 2007: Impacts, Adaptation and Vulnerability, Contribution of Working Group II to the Forth Assessment Report of the IPCC. Intergovernmental Panel on Climate Change. Cambridge University Press, Cambridge. UK.

[27]. Lal, M., H. Harasawa., and D. Murdiyarso., 2001. Asia In Climate Change 2001: Impacts, Adaptation, and Vulnerability, J. McCarthy, O. Canziani, N. Leary, D. Dokken, and K. White (eds.). Cambridge University Press, New York, pp. 533-590.

[28]. Ludi, E., 2009. "Climate change, water and food security". The Overseas Development Institute. UK.

[29]. Masum, S. J. H., and Hasan M. M. M., 2009 "Climate Change Impact on Food Sovereignty in Bangladesh". Submitted to On the Frontlines of Climate Change. Coastal Development Partnership (CDP), IUCN.

[30]. Nizamuddin. K., 2001. (Ed). Disaster in Bangladesh: Selected Readings. Disaster Research Training and Management Centre. University of Dhaka.

[31]. Parvaiz, A., 2009. "Food Security in Great Peril from Climate Change"U.N. Conference on Climate Change in Copenhagen on Dec 18.

[32]. Rahman. A., et al. Undated. "The Probable Impacts of Climate Change on Poverty and Economic Growth and the Options of Coping with Adverse Effect of Climate Change in Bangladesh". General Economics Division, Planning Commission, Government of the People's Republic of Bangladesh \& UNDP Bangladesh.

[33]. Rahman, A., 2010 "Climate Change in Bangladesh: Policies, Current Situation, Opportunities and Challenges". A presentation wa s presented on30 September in Beurs --World Trade Centre. The Netherlands.

[34]. Rahman, M.M., and Khan, S.I., 2005. "Food security in Bangladesh: Food availability". Presented Papers in the National Workshop. Ministry of Food and Disaster Management. Government Republic of Bangladesh. pp 7-16.

[35]. Rahman, A., and Mallick, D. L., 2010. Climate Change Impacts in Bangladesh. IRRI. Philippine.

[36]. Rasheed, K. B. S., 2008. Bangladesh: Resource and Environmental profile. A H Development Publishing House. Dhaka.

[37]. Sarwar,G. M., and Khan, M. H., 2007.Sea Level Rise: A Threat to the Coast of Bangladesh. Internationales Asienforum, Vol. 38, No. 3-4, pp. 375-397.

[38]. Schmidhuber, J., and Tubiello, F. N., 2007. Global food security under climate change. FAO. Columbia University, International Institute for Applied Systems Analysis. vol. 104 no. 50 pp 19703-19708.

[39]. Talukder, B., 2007. "Climate change and agriculture". Bangladesh Public Administration Training Centre (BPATC). Dhaka.

[40]. Yusuf. H. K. M., Dasgupta S., and Khan M.A. H., 2008. "Climate Change: An emerging threat to agriculture and food security in Bangladesh". FAO. Dhaka.

\section{Newspaper}

[41]. Akanda, A. I., 2012. Agricultural growth verses food security and safe- food security. New Age. 25 June.

[42]. Alam. M., 2012. There is no concern about the Food Situation:An Exclusive interview of Mahabub Hossain. The Daily Prothom Alo. 2 September.

\section{Internet}

[43]. (http://www.eea.europa.eu accessed on 19 April 2012).

[44]. (http://www.banglapedia.org/httpdocs/HT/P_0124.HTM accessed on 11 March 2012).

[45]. (http://en.wikipedia.org/wiki/Patuakhali_District accessed on 11 March 2012).

[46]. (http://www.banglapedia.org/httpdocs/HT/K_0030.HTM accessed on 11 March 2012).

[47]. (http://en.wikipedia.org/wiki/Kalapara_Upazila accessed on 19 June 2012)

[48]. (http://climate.nasa.gov/evidence/\#no4 accessed on 19 February 2012).

[49]. (http://www.banglapedia.org/httpdocs/HT/C_0376.HTM accessed on 19 June 2012) 